\title{
Among and within family selection and combined half-sib family selection in Panicum maximum Jacq. ${ }^{1}$
}

\author{
Janaina Azevedo Martuscello ${ }^{2}$, Liana Jank ${ }^{3}$, Dilermando Miranda da Fonseca ${ }^{4}$, Cosme \\ Damião $\mathrm{Cruz}^{5}$, Daniel de Noronha Figueiredo Vieira da Cunha ${ }^{6}$
}

\footnotetext{
1 Pesquisa financiada pelo CNPq e UNIPASTO.

2 Pós-doutoranda do Departamento de Zootecnia/UFV.

${ }^{3}$ Embrapa Gado de Corte. Bolsista do CNPq.

${ }^{4}$ Departamento de Zootecnia/UFV. Bolsista do CNPq.

5 Departamento de Biologia Geral/UFV. Bolsista da CNPq.

${ }^{6}$ Doutorando em Zootecnia/UFV.
}

\begin{abstract}
The objective of this study was to select superior genotypes in half-sib populations obtained from crosses between sexual plants and apomictic accessions. The experiment also proposed to compare among and within family and combined selection strategies. Ten plots of sexual plants were randomly distributed among 230 plots of apomictic accessions. After natural pollination, seeds of each sexual plant constituted a half-sib family. Thirty plants of each female progenitor were evaluated in a randomized block design experiment, with five plants per plot and five replications. Five evaluation harvests were made in the rainy seasons and two in the dry seasons of all plants. The production and quality characteristics were evaluated. The selection criteria used was: among and within family selection and combined selection with 50\% selection in both. The selection criteria used (among and within family selection and combined selection), were efficient for use in P. maximum breeding, with medium to high gains for most characteristics evaluated. The highest genetic gains were obtained from combined selection. However, among and within family selection promoted high genetic gains and may be used in P. maximum breeding. The sexual progenitors identified as numbers 7, 1, 3 and 5 were promising and may be used in future crosses, as well as to increase the genetic variability in the P.maximum genebank.
\end{abstract}

Key Words: forage yield, nutritive value, plant breeding, selection strategies

\section{Seleção entre e dentro de famílias e seleção combinada em famílias de meio-irmãos de Panicum maximum Jacq.}

RESUMO - O experimento foi conduzido objetivando-se selecionar genótipos e genitores superiores de Panicum maximum em populações de meio-irmãos, originárias do cruzamento de plantas sexuais com plantas apomíticas, bem como comparar estratégias de seleção entre e dentro de famílias e seleção combinada. Dez parcelas de plantas sexuais de P. maximum foram aleatoriamente distribuídas entre 230 parcelas de acessos apomíticos. Após a fecundação natural, sementes de cada planta sexual constituíram-se uma família de meio-irmãos. Trinta plantas de cada genitora foram avaliadas em delineamento de blocos ao acaso, com cinco plantas por parcela e cinco repetições. A partir da média de sete cortes (cinco na época das chuvas, a cada 35 dias, e dois na época da seca, um em cada seca), avaliaram-se as características de produção e o valor nutritivo dos genótipos. Foram utilizadas as estratégias de seleção entre e dentro de família e a seleção combinada, adotando-se porcentagem de seleção de $50 \%$ para ambas as estratégias. Os critérios de seleção utilizados mostraram-se eficientes para aplicação no melhoramento de P. maximum, com ganhos considerados de médio a alto. Os maiores ganhos genéticos foram obtidos com a seleção combinada, entretanto a seleção entre e dentro de família pode promover ganhos genéticos altos e pode ser utilizada no melhoramento de $P$. maximum. As famílias identificadas pelos números 1 , 3 , 5 e 7 são promissoras e podem ser utilizadas em futuros programas de melhoramento genético de P. maximum.

Palavras chave: melhoramento genético, métodos de seleção, produção de forragem, valor nutritivo

\section{Introduction}

In the cultivation of productive pastures, it is important to consider genetic aspects besides the development of new management techniques, since the optimization of the use of a forage is the result of actions and interactions of the genotype with the environment. Because Brazil is a country formed by various ecosystems, forage breeding 
will complement management actions and generate more productive plants adapted to different regions.

The main breeding methods of most tropical forage grasses primarily include evaluation and mass selection of genotypes selected from the genetic variability of ecotypes collected in Africa (Hacker and Jank, 1998; Valle et al., 2001). This selection process has been used extensively, and with success, in the breeding of forages of relevant importance in the Brazilian beef production system such as Panicum maximum Jacq. For this species, with apomictic reproduction, the introduction and mass selection based on germplasm are the most simple methodologies in the release of new cultivars.

Apomixis, as asexual reproduction, perpetuates superior genotypes with great precision. New cultivars of forages with apomictic reproduction may be released in the market from the selection of the best genotypes from the germplasm, or by the generation of new variability from crossings, which, in this case, makes the identification of plants from sexual reproduction absolutely necessary.

The discovery of diploid sexual plants in P. maximum permitted crossing and gene exchange but the artificial doubling of chromosome numbers was necessary for the cross of these plants with apomictic tetraploid plants to be feasible (Combes \& Pernes, 1970).

Progeny tests are commonly used in breeding to determine breeding values of progenitors and select superior individuals. According to Martins et al. (2005) there are many selection methods and choice depends on the magnitudes and sense of genetic gains and their ease of application. In this context, among and within family selection and combined selection are some of the options.

The objectives of this paper were to select superior genotypes and progenitors in $P$. maximum half-sib populations obtained from crosses between sexual and apomictic plants, and to compare among and within family and combined selection strategies.

\section{Material and Methods}

The experiment was carried out at Embrapa Gado de Corte. The climate according to Köppen is a tropical rainy savanna, subtype Aw, characterized by an irregular rain distribution with a well defined dry season during the cold months of the year and a rainy season during the summer months. During the experimental period the annual mean precipitation was around $1,640 \mathrm{~mm}$, the relative air humidity was $68 \%$ and the mean maximum and minimum temperatures were 29.8 and $19^{\circ} \mathrm{C}$, respectively.
The 250 accessions of $P$. maximum are conserved in the germplasm bank in the field in $4 \times 4$ m plots with $2 \mathrm{~m}$ between plots. Ten plots of sexual plants (tetraploids), whose chromosome numbers had been doubled by colchicines, were randomly distributed among the apomictic accessions (tetraploids).

During the flowering period of each year (March to May), the sexual plants were naturally pollinated by neighboring accessions, resulting in seeds of half-sib families. Hybrid seeds of the 10 sexual plants were harvested in May-June 2003 and 2004, and seeded in October in styrophome trays with vermiculite:sand (1:1) substrate. After two months, 30 seedlings of each sexual progenitor were transplanted to soil in plastic bags and maintained until adequate conditions for transplant in the field.

The soil of the experimental area is classified as a latossolo vermelho (oxisol) (Embrapa, 1999) with the following characteristics: $\mathrm{pH} \mathrm{CaCl}_{2} 4.53 ; \mathrm{P}=1.29 \mathrm{mg} \mathrm{dm}^{-3}$; $\mathrm{K}=48.6 \mathrm{mg} \cdot \mathrm{dm}^{-3} ; \mathrm{Ca}^{2+}=1.64 \mathrm{cmol}_{\mathrm{C}} \cdot \mathrm{dm}^{-3} ; \mathrm{Mg}^{2+}=0.93 \mathrm{cmol}_{\mathrm{C}} \cdot \mathrm{dm}^{-3}$; $\mathrm{H}+\mathrm{Al}=8.31 \mathrm{cmol}_{\mathrm{C}} \cdot \mathrm{dm}^{-3}$.

Dolomitic lime at the rate of $3 \mathrm{t}^{-h a^{-1}}$ was applied to the soil on the $0-20 \mathrm{~cm}$ layer at the beginning of November 2005. Phosphorous and potassium fertilizers consisted of $100 \mathrm{~kg} \cdot \mathrm{ha}^{-1} \mathrm{P}_{2} \mathrm{O}_{5}$ (super simple phosphate) and $100 \mathrm{~kg}$.ha- ${ }^{-1}$ $\mathrm{K}_{2} \mathrm{O}$ (potassium chlorate), respectively. A micronutrient mixture of $50 \mathrm{~kg}$.ha ${ }^{-1}$ FTE BR16 was also applied. Nitrogen fertilizer was applied at transplant as $100 \mathrm{~kg} \cdot \mathrm{ha}^{-1} \mathrm{~N}$ (urea).

In December 2005, the seedlings (per progeny) were transplanted to the experimental area in a randomized complete block design, with five plants per plot and five replications, spaced $1 \mathrm{~m}$ between plots and between plants in a plot and $2 \mathrm{~m}$ between replications.

In December 2006, the phosphorous, potassium and nitrogen fertilizers were reapplied at the same rates as previously.

Five harvests were made of all plants at $20 \mathrm{~cm}$ height from the soil, during the rainy seasons (March, April and December 2005, January and March 2006) and two during the dry seasons (October 2005 and October 2006). Immediately after the harvests, forage mass was weighed to obtain the green matter production (GM). Samples of the plants were separated into leaf blades, leaf sheaths + stems and dead material, and then were air-forced dried at $65^{\circ} \mathrm{C}$ for 72 hours and weighed to estimate total dry matter yield (DMY), leaf dry matter yield (LDMY), leaf percentage, stem percentage and dry matter percentage in each genotype. The samples were ground in a Wiley mill, using a $1 \mathrm{~mm}$ screen and analyzed for quality at the Embrapa Beef Cattle Animal Nutrition Laboratory by Near-infrared Reflectance Spectroscopy (NIRS). The following 
characteristics were evaluated: crude protein (CP), neutral detergent fiber (NDF), lignin (LIG), in vitro organic matter digestibility (IVOMD).

Promising plants for both seasons of the year (rainy and dry) were selected among and within families in an unbalanced experiment according to the methodology by Cruz (2006). Some plants did not survive the entire the experimental period and it was necessary to estimate the yields of these plants from the data of other progenies of the same female progenitor. The best plants within the best families were selected. Percentage selection among families was $50 \%$, totaling five superior families. For each selected family, a superior plant in each of the five blocks was identified, totaling 25 selected plants. With the exception of stem percentage, dead material percentage, lignin concentration in leaves and stems and NDF in leaves and stems, all the characteristics were selected in the positive direction, i.e. to obtain increase in the original means.

Gains obtained from selection among and within $P$. maximum half-sib families were estimated for each variable, according to Cruz (2006):

Gain obtained from among family selection was estimated as follows:

$\mathrm{GSa}=h^{2}{ }_{m} \mathrm{DS}$

in which:

GSa: gain obtained from among family selection;

$h^{2}{ }_{m}$ : mean family heritability

$D S=\overline{X_{S}}-\overline{X_{O}}$ : selection differential; and

$\overline{X_{O}}$ and $\overline{X_{S}}$ : original mean and mean of the selected individuals, respectively.

Gain obtained from within family selection was calculated as follows:

$$
\mathrm{GS}_{\mathrm{w}}=\mathrm{h}^{2}{ }_{\mathrm{d}} \mathrm{DS} \mathrm{m}_{\mathrm{m}}
$$

in which:

$\mathrm{GS}_{\mathrm{w}}$ : Gain obtained from within family selection;

$\mathrm{h}_{\mathrm{d}}^{2}$ : heritability at the plot level (among plants within families), that was estimated from within family genotypic and phenotypic variance and covariance matrices;

$\mathrm{DS}_{\mathrm{m}}=$ mean selection differential within the various plots of the selected families.

Gain obtained from among and within family selection was calculated as follows:

$$
\mathrm{G}_{\mathrm{aw}}=\mathrm{GS}_{\mathrm{a}}+\mathrm{GS}_{\mathrm{w}}
$$

Through this procedure, among and within family gains were estimated, selected families were listed and all the selected individuals were identified, within each family and for each block.

In the selection of best families and best genotypes based on combined selection, index 2 was used, in which the value of the individual in relation to the mean of the block is considered:

$$
\text { Index 2: } G_{i j k}=\beta_{i}\left(Y_{i j k}-\bar{Y}_{. . j}\right)+\beta_{f}\left(\bar{Y}_{i . .}-\bar{Y}_{. .}\right)
$$

in which:

$G_{i j k}$ : predictor of the genetic value of the individual;

$\beta_{i}$ : weight of the individual value in the index; and

$\beta_{f}$ : weight of the family value in the index.

To estimate the weights of the individual and of the family in the index, the following expression was used:

$$
G_{i j k}=\beta_{i} Z_{1}+\beta_{f} Z_{2}
$$

The vector $b$, was estimated as:

$P b=G$

in which:

$b=\left[\begin{array}{c}\beta_{i} \\ \beta_{f}\end{array}\right], \quad P=\left[\begin{array}{cc}V\left(Z_{1}\right) & \operatorname{Cov}\left(Z_{1}, Z_{2}\right) \\ V\left(Z_{2}\right)\end{array}\right]$ e $\quad G=\left[\begin{array}{c}\operatorname{Cov}\left(Z_{1}, G_{i j k}\right) \\ \operatorname{Cov}\left(Z_{2}, G_{i j k}\right)\end{array}\right]$

The correlation between the index and the genotypic aggregate was also estimated, using the following expression:

$$
r_{H I}=\frac{\operatorname{Cov}(H, I)}{\sqrt{\hat{V}(I) \hat{V}(H)}}=\sqrt{\frac{b^{\prime} P b}{\sigma_{a}^{2}}}
$$

Gain obtained from selection based on the index, was estimated as:

$G S=D S_{I}$

in which:

$D S_{I}$ : selection differential based on the combined index, i.e.: in which:

$D S_{I}=\bar{I}_{s}-\bar{I}$

$\bar{I}_{s}$ : mean value of the index, considering only the selected individuals; and

$\bar{I}$ : mean value of the index (equal to zero, for the indexes considered in the analysis).

Through this procedure the number of individuals selected per family was listed, gain obtained from the combined selection was estimated and the efficiency of the combined selection in relation to among and within family selection was quantified.

\section{Results and Discussion}

The characteristics stem percentage, percent dead material, LIG in leaves and stems and NDF in leaves and stems presented negative genetic gain values due to the fact that selection was made in the sense of decreasing values, this is, individuals with less accumulation of stems and dead material were sought, as well as with smaller concentrations of lignin and NDF, characteristics that present an inverse relationship with the forage digestibility with a consequent effect on animal performance. 
In the rainy season, gain obtained from within family selection (GSd\%) was greater than gain obtained from among family selection (GSe\%) for the characteristics GM, DMY, LDMY and stem percentage (Table 1). Thus, it is emphasized that for most production characteristics during the rainy season, there was more within family than among family variability. In this case, within family selection may contribute with considerable gains for these characteristics.

In the dry season (Table 2), gains from within family selection (GSd\%) were greater than from among family selection (GSa\%) for the following characteristics: GM, DMY, leaf percentage, LDMY, dead matter percentage, LIG in stems and NDF in stems. For the remaining characteristics (stem percentage, LIG in leaves and stems, IVOMD in leaves and stems, NDF in leaves and CP in leaves and stems), gain from among family selection (GSa\%) was greater than gain from within family selection (GSw\%).
The greatest gain estimated from within family selection was for the characteristic LDMY, both in the rainy season (Table 1 ) as well as in the dry season (Table 2), with values of 38,67 and 58,49, respectively.

The LDMY characteristic is possibly the one of greatest interest for forage breeders of cespitose species, since leaf accumulation is favorable for animal production because of the higher quality of the leaves that are more digestible than the stems. This fact was confirmed since leaf digestibility was greater than stem digestibility, both for the original means and for the means of the selected individuals (Tables 1 e 2). Expressive gains for this characteristic may significantly contribute to the success of the $P$. maximum breeding program, since a forage with greater leaf yield tends to be more consumed by the grazing animals, if management aspects are considered and the leaf biomass may be efficiently harvested by the animal.

Table 1 - Gains obtained from among (GSa), within (GSw) and among and within family selection (GSt) and means of the original population $\left(\mathrm{X}_{0}\right)$ and of the selected individuals $\left(\mathrm{X}_{\mathrm{S}}\right)$ for the evaluated characteristics in $P$. maximum half-sibs in the rainy season

\begin{tabular}{|c|c|c|c|c|c|}
\hline Characteristic & GSa (\%) & GSw (\%) & GSt (\%) & Xo & Xs \\
\hline Green matter yield (g) & 12.64 & 21.96 & 34.60 & 980.74 & 1158.79 \\
\hline Dry matter yield (g) & 9.87 & 17.35 & 27.22 & 239.86 & 273.90 \\
\hline$\%$ leaves & 12.46 & 9.84 & 22.30 & 60.84 & 69.60 \\
\hline$\%$ stems & -16.86 & -21.98 & -38.84 & 33.56 & 27.48 \\
\hline \% Dead material & -8.36 & -7.39 & -15.75 & 1.94 & 1.22 \\
\hline Lignin in leaves (\%) & -4.26 & -3.46 & -7.72 & 2.75 & 2.31 \\
\hline IVOMD in stems (\%) & 0.00 & 0.00 & 0.00 & 47.40 & 49.15 \\
\hline NDF in leaves (\%) & -2.88 & -0.73 & -3.61 & 70.58 & 71.19 \\
\hline NDF in stems (\%) & 0.00 & 0.00 & 0.00 & 73.93 & 71.19 \\
\hline CP in leaves (\%) & 1.28 & 1.25 & 2.53 & 10.74 & 11.56 \\
\hline $\mathrm{CP}$ in stems (\%) & 0.00 & 0.00 & 0.00 & 6.37 & 7.01 \\
\hline
\end{tabular}

GS: gains obtained from selection; GSa: gains obtained from among family selection $\left(\mathrm{GSa}=\mathrm{DS} * \mathrm{~h}^{2}\right)$; GSw: gains obtained from within family selection $\left(\mathrm{GSD}=\mathrm{DS} * \mathrm{~m} * \mathrm{~h}^{2}\right)$; GSt: total gains obtained from selection (GSt=GSa+GSw); IVOMD: in vitro organic matter digestibility; NDF: neutral detergent fiber; CP: crude protein (\%).

Table 2 - Gains obtained from among s (GSa), within (GSw) and among and within family selection (GSt) and means of the original population $\left(\mathrm{X}_{0}\right)$ and of the selected $\left(\mathrm{X}_{\mathrm{S}}\right)$ for the evaluated characteristics in $P$. maximum half-sibs in the dry season

\begin{tabular}{|c|c|c|c|c|c|}
\hline Characteristic & GSa (\%) & GSw (\%) & GSt (\%) & Xo & Xs \\
\hline Green matter yield (g) & 21.13 & 43.92 & 65.05 & 1289.99 & 1609.20 \\
\hline Dry matter yield (g) & 21.46 & 44.81 & 66.27 & 438.45 & 543.05 \\
\hline$\%$ leaves & 13.79 & 21.39 & 35.18 & 42.24 & 48.95 \\
\hline$\%$ stems & -35.54 & -30.71 & -66.25 & 20.53 & 13.08 \\
\hline$\%$ Dead matter & -8.80 & -11.55 & -20.35 & 33.25 & 28.72 \\
\hline Lignin in leaves (\%) & -10.51 & -9.12 & 19.63 & 2.81 & 2.02 \\
\hline IVOMD in stems (\%) & 12.68 & 7.35 & 20.03 & 35.90 & 42.53 \\
\hline NDF in leaves (\%) & -2.52 & -2.01 & -4.53 & 68.08 & 62.77 \\
\hline NDF in stems (\%) & -12.60 & -22.47 & -35.07 & 61.72 & 51.29 \\
\hline $\mathrm{CP}$ in leaves $(\%)$ & 3.86 & 3.24 & 7.10 & 9.55 & 10.79 \\
\hline $\mathrm{CP}$ in stems $(\%)$ & 31.70 & 18.98 & 50.68 & 3.78 & 5.64 \\
\hline
\end{tabular}

GS: gains obtained from selection; GSe: gains obtained from among family selection (GSa $\left.=\mathrm{DS} * \mathrm{~h}^{2}\right)$; GSw: gains obtained from within family selection $\left(\mathrm{GSD}=\mathrm{DS} * \mathrm{~m} * \mathrm{~h}^{2}\right)$; GSt: total gains obtained from selection (GSt=GSa+GSw); IVOMD: in vitro organic matter digestibility; NDF: neutral detergent fiber; $\mathrm{CP}$ : crude protein (\%). 
Since the stem percentage of the forage is a characteristic dependent on the leaf percentage, high values of gains from selection were also obtained. The GSt was -38.84 and -66.25 during the rainy and dry seasons, respectively (Tables 1 and 2, respectively). The gains were nill for the leaf and stem IVOMD characteristics (rainy season), indicating that breeding for this characteristic may not be efficient.

Selection of forages with lower stem percentage, and, consequently higher leaf percentage, and evidently, still considering LDM, assumes a primary role in P. maximum breeding, since the species is of cespitose growth, which per se, tends to promote a higher stem accumulation. Thus, a high GSt (in the sense of decrease) for stem percentage may be an indicative that promising genotypes may arise from this selection.

Selection processes aim at identifying, within preestablished criteria, the best individuals and/ or families that should remain in the breeding program generating more productive populations, according to the breeders' interests (Negreiros, 2006). Selection does not create variability, but acts in the existing variability (Allard, 1971). In this context, selection of superior genotypes, either individuals or families, is a practice of considerable relevancy to the breeder, since improved populations are obtained from selection and recombination of these individuals or families. In P. maximum, selection, both among and within family selection is of primary importance, since superior sexual plants may be used in future crosses and increase genetic variability.

Families 7 and 1 were selected for almost all the characteristics evaluated in the rainy season (Table 3). For family 7 exceptions were percent dead matter, IVOMD and

Table 3 - Selected families from within half-sib family selection in $P$. maximum in the rainy and dry seasons

\begin{tabular}{lcc}
\hline \multirow{2}{*}{ Characteristic } & \multicolumn{2}{c}{ Selected family } \\
\cline { 2 - 3 } Green matter yield & Rainy season & Dry season \\
Dry matter yield & $3,5,8,7,4$ & $3,8,5,9,4$ \\
\% leaves & $3,7,4,5,6$ & $8,3,5,9,7$ \\
Leaf dry matter yield & $5,7,6,3,1$ & $3,5,1,4,8$ \\
$\%$ stems & $5,5,7,1,6$ & $3,5,1,4,8$ \\
$\%$ Dead matter & $10,4,1,5,9$ & $10,1,5,2,7$ \\
Lignin in leaves & $7,3,5,8,6$ & $4,8,3,9,10$ \\
Lignin in stems & $8,7,9,3,1$ & $6,2,10,4,1$ \\
IVOMD in leaves & $10,6,1,2,4$ & $2,10,5,6,1$ \\
IVOMD in stems & $10,9,8,1,4$ & $9,8,7,3,5$ \\
NDF in leaves & $3,7,8,6,1$ & $9,8,3,4,7$ \\
NDF in stems & $8,5,9,7,1$ & $10,6,4,2,1$ \\
CP in leaves & $10,2,4,1,6$ & $2,10,5,6,1$ \\
CP in stems & $10,9,8,1,7$ & $9,8,7,3,5$ \\
\hline
\end{tabular}

IVOMD: in vitro organic matter digestibility; NDF: neutral detergent fiber; CP: crude protein (\%).
CP in leaves. For family 1, exceptions were GM, DMY and LIG in leaves. The data indicated that family 1 may be used in breeding programs that aim at obtaining gains related to forage nutritive value.

In the rainy season, the individuals with higher LDMY in family 7 were: 1 and 2 (Blocks 1 and 2), 2 and 1 (Block 3 ) and 4 and 2 (Blocks 4 and 5). In family 1 they were: 5 and 1 (Block 1), 3 and 2 (Block 2), 2 and 1 (Block 3), 4 and 3 (Block 4) and 3 and 5 (Block 5). The knowledge of the reproductive mode of these individuals will be essential to determine whether the plants will continue to be evaluated in other phases of study aiming at commercial release, or will be included in the P. maximum sexual germplasm bank at Embrapa Beef Cattle.

In the dry season, families 3 and 5 were selected for most evaluated characteristics. However, as the gains obtained from within family selection (GSw\%) were higher than the gains obtained from among family selection (GSa\%) for most characteristics, selection within these selected families would indicate the best individuals. Thus, for LDMY, characteristic considered of greatest interest in $P$. maximum breeding, the superior individuals within family 3 were: 5 and 4 (Block 1), 4 and 1 (Blocks 2 and 4), 5 and 2 (Blocks 3 and 5). In family 5 the superior individuals were: 4 and 3 (Block 1), 3 and 1 (Blocks 2, 3 and 4) and 2 and 3 (Block 5).

Combined selection differs from the conventional among and within family selection, because it considers the individual value and the family means in a weighted manner. In this case, an index is generated resulting in a differentiated number of families and of individuals selected per family, while this number is constant in among and within family selection.

In the rainy season, for the characteristics leaf percentage, LDMY, stem percentage and LIG in leaves the index related to the weight of the individual $\left(b_{1}\right)$ was superior to the index related to the family weight $\left(b_{2}\right)$, thus, for these characteristics a higher weight was attributed to within family selection (Table 4). For the remaining characteristics, the inverse was observed, this is, a higher value was attributed to among family selection. In the dry season, a higher value was attributed to among family selection for all characteristics except for DMY and LIG in stems.

These results indicated, according to Negreiros (2006), that selection considering the information of individuals and families at only one stage (combined selection), may be more efficient in terms of response percentile, than selection of families and individuals at two different stages (selection among and within families). 
Table 4 - Estimates of weights related to the individual value of the plant $\left(b_{1}\right)$, of the family $\left(b_{2}\right)$ and to the relative value $b_{2} / b_{1}$ for the evaluated characteristics in $P$. maximum half-sib families

\begin{tabular}{|c|c|c|c|c|c|c|}
\hline \multirow[t]{2}{*}{ Characteristic } & \multicolumn{3}{|c|}{ Rainy season } & \multicolumn{3}{|c|}{ Dry season } \\
\hline & $\mathrm{b}_{1}$ & $\mathrm{~b}_{2}$ & $\mathrm{~b}_{1} / \mathrm{b}_{2}$ & $\mathrm{~b}_{1}$ & $\mathrm{~b}_{2}$ & $\mathrm{~b} 1 / \mathrm{b}_{2}$ \\
\hline Green matter yield & 0.40 & 0.45 & 0.89 & 0.80 & 0.25 & 3.14 \\
\hline Dry matter yield & 0.37 & 0.49 & 0.75 & 0.85 & 0.21 & 3.93 \\
\hline$\%$ leaves & 1.32 & 0.01 & 132.15 & 1.02 & 0.01 & 102.42 \\
\hline Leaf dry matter yield & 0.70 & 0.30 & 2.41 & 0.87 & 0.16 & 5.30 \\
\hline$\%$ stems & 1.80 & 0.01 & 179.89 & 4.01 & 0.01 & 401.50 \\
\hline$\%$ Dead matter & 0.12 & 0.22 & 0.53 & 0.41 & 0.38 & 1.07 \\
\hline Lignin in leaves & 0.73 & 0.26 & 0.28 & 0.10 & 0.37 & 0.28 \\
\hline Lignin in stems & 0.05 & 0.18 & 0.26 & 0.43 & 0.48 & 0.89 \\
\hline IVOMD in leaves & 0.01 & 0.01 & 1.00 & 0.11 & 0.41 & 0.26 \\
\hline IVOMD in stems & 0.01 & 0.01 & 1.00 & 0.35 & 0.50 & 0.69 \\
\hline NDF in leaves & 0.06 & 0.23 & 0.24 & 0.09 & 0.31 & 0.29 \\
\hline NDF in stems & 0.01 & 0.01 & 1.00 & 0.45 & 0.47 & 0.94 \\
\hline $\mathrm{CP}$ in leaves & 0.04 & 0.17 & 0.24 & 0.08 & 0.31 & 0.25 \\
\hline $\mathrm{CP}$ in stems & 0.01 & 0.01 & 1.00 & 0.35 & 0.44 & 0.78 \\
\hline
\end{tabular}

IVOMD: in vitro organic matter digestibility; NDF: neutral detergent fiber; CP: crude protein (\%).

Table 5 - Gains obtained from selection by the method of combined selection $\left(\mathrm{GS}_{\mathrm{C}}\right)$, among and within family selection (GSaw), mass selection $\left(\mathrm{GS}_{\mathrm{M}}\right)$, stratified mass selection $\left(\mathrm{GS}_{\mathrm{ME}}\right)$ and efficiency of combined selection in relation to among and within $P$. maximum half-sib family selection

\begin{tabular}{|c|c|c|c|c|c|c|}
\hline Characteristic & $\mathrm{GS}_{\mathrm{C}}$ & $\mathrm{GS}_{\mathrm{aw}}$ & Efficiency $\left(\mathrm{S}_{\mathrm{C}} / \mathrm{S}_{\mathrm{aw}}\right)$ & $\mathrm{GS}_{\mathrm{C}}$ & $\mathrm{GS}_{\mathrm{aw}}$ & Efficiency $\left(\mathrm{S}_{\mathrm{C}} / \mathrm{S}_{\mathrm{aw}}\right)$ \\
\hline Green matter yield & 42.79 & 34.60 & 1.23 & 76.32 & 65.05 & 1.17 \\
\hline Dry matter yield & 34.57 & 27.22 & 1.26 & 75.33 & 66.27 & 1.13 \\
\hline$\%$ leaves & 54.00 & 22.30 & 2.42 & 46.06 & 35.18 & 1.31 \\
\hline Leaf dry matter yield & 67.09 & 59.21 & 1.13 & 92.11 & 79.03 & 1.16 \\
\hline$\%$ stems & -103.69 & -38.84 & 2.67 & -396.31 & -66.25 & 5.57 \\
\hline \% Dead matter & -34.27 & -15.75 & 2.17 & -26.70 & -20.35 & 1.31 \\
\hline Lignin in leaves & -13.36 & -7.72 & 1.73 & -24.06 & -19.63 & 1.22 \\
\hline Lignin in stems & -6.82 & -3.88 & 1.75 & -181.08 & -153.71 & 1.18 \\
\hline IVOMD in leaves & 0.00 & 0.00 & 0.00 & 7.62 & 3.95 & 1.93 \\
\hline IVOMD in stems & 0.00 & 0.00 & 0.00 & 37.46 & 20.03 & 1.87 \\
\hline NDF in leaves & -2.94 & -3.61 & 0.81 & -5.70 & -4.53 & 1.26 \\
\hline NDF in stems & 0.00 & 0.00 & 0.00 & -42.58 & -35.07 & 1.21 \\
\hline $\mathrm{CP}$ in leaves & 3.63 & 2.53 & 1.43 & 9.50 & 7.10 & 1.34 \\
\hline $\mathrm{CP}$ in stems & 0.00 & 0.00 & 0.00 & 99.92 & 50.68 & 1.97 \\
\hline
\end{tabular}

IVOMD: in vitro organic matter digestibility; NDF: neutral detergent fiber; CP: crude protein (\%).

Genetic gains varied with the characteristics (Table 5), but in general, may be considered high, especially for the production characteristics (GM, DMY, leaf percentage, LDMY, stem percentage). For all the evaluated characteristics, with the exception of leaf NDF in the rainy season, the $\mathrm{GS}_{\mathrm{C}}$ estimates obtained were superior to the $\mathrm{GS}_{\mathrm{t}}$ estimates, in so much that this characteristic was the only one to present a value of efficiency of combined selection in relation to among and within family selection inferior to 1 (Table 5). In the literature, the comparison is common between the gains obtained from combined selection and among and within family selection (Rosado, 2003; Costa et al., 2000; Martins et al., 2005; Pires et al., 1996). The estimates of gains obtained from selection for $P$. maximum are the objectives of very few reports (Oliveria,1997; Resende et al., 2004).
The results (Table 5) suggested that combined selection should be preferred as a method of candidate classification (families and individuals) for selection. However, despite the apparent superiority of combined selection, the processes of among and within family selection also provided expressive genetic gains and, as they are simpler to use, should continue to be considered as an instrument of classification of candidates for selection.

According to Martins et al. (2005) another important consideration of combined selection is the number of selected families, because although this method is usually superior to among and within family selection, it may lead to the selection of very few families, which would not be desirable in terms of genetic basis. Especially for $P$. maximum breeding this should be cautiously evaluated, since few sexual plants were used in the crossings, and in 
this case, there is a need to select the superior individuals (sexual) so that variability can be increased and consequently the feasibility of future crosses.

Analysis of both evaluation periods shows that families 3,5 and 7 were superior, and most of the 50 selected individuals belonged to them (Table 6). In fact, these families were the most outstanding in the process of within family selection.
P. maximum breeding studies should also consider, in addition to production and nutritive value characteristics, resistance to pests and diseases, hydric, aluminum and saline stresses among others, and evaluate characteristics inherent to soil fertility. Furthermore, future studies should also consider genotype $\times$ environment interactions, since this evaluation is necessary for the release of a new cultivar.

Table 6 - Selected plants and their respective phenotypic values (g) for leaf dry matter yield by combined selection in P. maximum half-sib families

\begin{tabular}{|c|c|c|c|c|c|c|c|c|c|}
\hline \multicolumn{5}{|c|}{ Rainy season } & \multicolumn{5}{|c|}{ Dry season } \\
\hline $\mathrm{Nb}$ & Family & Block & Plant & g & $\mathrm{Nb}$ & Family & Block & Plant & g \\
\hline 1 & 3 & 4 & 4 & 524.57 & 1 & 5 & 2 & 5 & 719.30 \\
\hline 2 & 3 & 3 & 5 & 508.31 & 2 & 3 & 4 & 4 & 753.82 \\
\hline 3 & 4 & 5 & 5 & 548.04 & 3 & 5 & 5 & 5 & 770.32 \\
\hline 4 & 1 & 1 & 5 & 481.00 & 4 & 1 & 3 & 4 & 575.84 \\
\hline 5 & 5 & 2 & 1 & 453.45 & 5 & 3 & 5 & 5 & 543.64 \\
\hline 6 & 4 & 3 & 3 & 464.24 & 6 & 3 & 3 & 5 & 566.52 \\
\hline 7 & 3 & 4 & 5 & 422.43 & 7 & 5 & 3 & 5 & 477.95 \\
\hline 8 & 5 & 2 & 5 & 436.39 & 8 & 5 & 5 & 3 & 637.97 \\
\hline 9 & 3 & 5 & 5 & 411.11 & 9 & 5 & 5 & 4 & 425.13 \\
\hline 10 & 5 & 5 & 5 & 417.44 & 10 & 3 & 4 & 5 & 599.82 \\
\hline 11 & 3 & 1 & 5 & 327.36 & 11 & 3 & 3 & 2 & 468.03 \\
\hline 12 & 7 & 2 & 1 & 351.35 & 12 & 3 & 2 & 1 & 431.21 \\
\hline 13 & 5 & 2 & 2 & 349.55 & 13 & 1 & 5 & 5 & 437.80 \\
\hline 14 & 1 & 1 & 1 & 339.10 & 14 & 3 & 1 & 5 & 408.16 \\
\hline 15 & 7 & 5 & 4 & 350.12 & 15 & 5 & 3 & 1 & 383.67 \\
\hline 16 & 7 & 3 & 2 & 322.52 & 16 & 2 & 5 & 5 & 457.65 \\
\hline 17 & 3 & 1 & 4 & 288.94 & 17 & 10 & 2 & 5 & 410.64 \\
\hline 18 & 3 & 2 & 4 & 298.81 & 18 & 5 & 1 & 4 & 285.18 \\
\hline 19 & 7 & 2 & 2 & 312.84 & 19 & 1 & 3 & 3 & 402.63 \\
\hline 20 & 4 & 5 & 2 & 346.16 & 20 & 8 & 1 & 5 & 351.12 \\
\hline
\end{tabular}

\section{Conclusions}

The selection criteria used proved to be efficient for Panicum maximum breeding, but the greatest genetic gains were obtained from combined selection. However, among and within family selection resulted in high genetic gains and may be used in P. maximum breeding. Female progenitors 7, 1, 3 and 5 were promising and may be used in future crosses in P. maximum. The reproductive mode of the selected hybrids should be determined to decide on the continuation of these hybrids in the $P$. maximum breeding program, if apomictic they will follow subsequent agronomic and animal performance evaluation tests and if sexual they will replenish the germplasm bank.

\section{Literature Cited}

ALLARD, R.W. Princípios de melhoramento genético das plantas. São Paulo: Edgard Blücher, 1971. 381p.

BUENO, L.C.S.; MENDES, A.N.G.; CARVALHO, S.P. Melhoramento genético de plantas. Lavras: Editora UFLA. 2001. 282p.
COMBES, D.; PÉRNES, J. Variation dans les nombres chromosomiques du Panium maximum en relation avec le mode de reproduction. Comptes Rendues Academie Science, v.270, p.782-785, 1970.

COSTA, R.B.; RESENDE, M.D.V.; ARAÚJO, A.J. et al. Seleção combinada univariada e multivariada aplicada ao melhoramento genético da seringueira. Pesquisa Agropecuária Brasileira. v.35, n.2, p.381-388, 2000.

CRUZ, C.D. Programa Genes: Biometria. Viçosa, MG: Editora UFV, 2006. 382p.

HACKER, J.B.; JANK, L. Breeding tropical and subtropical grasses. In: CHERNEY, J.H.; CHERNEY, D.J.R. (Eds.) Grass for dairy cattle. Cambridge: CABI Publishing, 1998. p.49-72.

MARTINS, I.S.; CRUZ, C.D.; ROCHA, M.G.B. et al. Comparação entre os processos de seleção entre e dentro de seleção combinada em progênies de Eucalyptus grandis. Revista Cerne, v.11, n.1, p.14-21, 2005.

NEGREIROS, J.R.S. Seleção combinada, massal e entre e dentro, análise de trilha e repetibilidade em progênies de meios irmãos de maracujazeiro (Passiflora edulis f. flavicarpa). 2006. 128f. Tese (Doutorado em Genética e Melhoramento) Universidade Federal de Viçosa, Viçosa, MG, 2006.

OLIVEIRA, A.C. Avaliação de progenies segregantes, familias clonais, hibridos F1 apomiticos e cultivares de capimcolonião (Panicum maximum Jacq.) quanto ao estresse de aluminio em solução nutritiva. 1997. 122f. Dissertação (Mestrado em Biologia) - Universidade Estadual de Campinas, Campinas, 1997. 
PIRES, I.E. Eficiência da seleção combinada no melhoramento genético de Eucaliptus spp. 1996. 128f. Tese (Doutorado em Genética e Melhoramento) - Universidade Federal de Viçosa, Viçosa, MG, 1996.

RESENDE, R.M.S.; JANK, L.; VALLE, C.B. et al. Biometrical analysis and selection of tetraploid progenies of Panicum maximum Jacq. using mixed model methodology. Pesquisa Agropecuária Brasileira, v.39, n.4, p.335-341, 2004.
ROSADO, A.M. Seleção entre e dentro de famílias e baseada nos valores genéticos obtidos pelo índice combinado e BLUP em eucalipto. 2003. 76f. Tese (Doutorado em Genética e Melhoramento) - Universidade Federal de Viçosa, Viçosa, MG, 2003.

VALLE, C.B.; PEREIRA, A.V.; JANK, L. Melhoramento de forrageiras tropicais. In: CONGRESSO BRASILEIRO DE MELHORAMENTO DE PLANTAS, 1., 2001. Goiânia. Anais... Goiânia: EmbrapaCNPAF; Universidade Federal de Goiás, 2001. 